\title{
Islamic Religious Education Learning to Develop 4cs Through Blended Learning Method E-Poster Comment: Research at SMAN 27 Bandung City
}

\author{
Edi Prihadi, Supiana, Aan Hasanah, Asep Nursobah \\ Universitas Islam Negeri (UIN) Sunan Gunung Djati Bandung, Indonesia \\ Email: ediprihadi@gmail.com, supiana@uinsgd.ac.id, aanhasanah@uinsgd.ac.id, \\ asepnursobah@uinsgd.ac.id
}

\section{ARTICLE INFO ABSTRACT}

Received

08 September 2021

Revision

This research is motivated by the challenges of developing the

13 September 2021

Approved

21 September 2021

Keywords:

dress code;

4Cs skills;

blended learning

method poster

comment

Indonesian nation in the 21st century, namely preparing a young generation who is flexible, creative, and proactive. The young age needs to be formed so that they are skilled in problem-solving, wise in making decisions, thinking creatively, consulting, creating ideas effectively, and wor So that 21st-century skills or 4Cs need to be developed in learning, including PAI learning. This study aims to identify PAI learning to develop 4Cs at SMAN 27 Bandung and the effectiveness of PAI learning to develop 4Cs at SMAN. PAI learning is not limited to normative education obtained by memorizing. PAI is required to interpret and answer various current and future problems. PAI is needed to develop students' skills which include four skills, namely critical thinking skills, creative thinking skills, communication skills, and collaboration skills, especially in solving contemporary problems using the Islamic perspective. Thus PAI learning also has a great responsibility in developing 4Cs. Therefore, the task of educators is to condition learning so that all aspects of the 21st-century skills (Critical Thinking, Creative Thinking, Communication, and Collaboration) can be trained. The approach used in this research is qualitative with the descriptiveanalytical method. Data were collected through observation, interviews, and documentation studies. The subjects of this study were teachers, students, school principals, and vice-principals in the field of curriculum. In general, PAI learning to develop 4Cs skills has been well implemented to achieve indicators of 4Cs skills. The PAI learning process to establish 4Cs at SMAN 27 Bandung City took place quite effectively, marked by the majority of students being enthusiastic in learning, which was marked by their seriousness in participating in learning, giving opinions during discussions responding to the views of their friends. Students understand the material quite well, characterized by providing statements and choosing one of the pictures according to the group questions in the e-poster and the reasons.

\section{INTRODUCTION}

The 21st century is a century full of challenges. With the rapid development of information technology and the increasing speed of communication, with just one touch, almost all forms of communication can be carried out in a few seconds, as if the world is in the palm of your hand. The real challenge of the 21st century is the increasing demand for education that can meet global needs, which requires literate individuals, character, and 4Cs skills (Critical Thinking \& Innovation,
How To Cite:

E-Issn:

Published By:
Prihadi, E., et. al. (2021) Islamic Religious Education Learning to Develop 4cs Through Blended Learning Method E-Poster Comment: Research at SMAN 27 Bandung City. Jurnal of Social Science. 2(5). https://doi.org/10.46799/jss.v2i5.219

2721-5202

Ridwan Institut 
Communication, collaboration, and Creativity $\&$ innovation) (Afandi, 2017).

This is in line with the characteristics of 21st-century skills issued by the Partnership of 21st Century Skills. It is determined that 21st-century students must be literate, have a strong character, and develop the competitive skills needed in the 21st century, such as critical thinking, problem-solving, communication skills, ICT literacy, information and communication technology, and information literacy. And media literacy (Hariyanto, 2014). 21st-century skills that students must possess include 4C skills, namely critical thinking, creative thinking, communication, and collaboration. To develop properly, students need to be familiarized with learning activities that develop the 4Cs. Thus, all learning activities, including PAI learning, besides being directed at literacy and character development, must also develop 4Cs skills.

Based on the initial observations of the teaching and learning process carried out in class at SMA Negeri 27 Bandung City, critical thinking skills, creative thinking, communication skills, and collaboration as aspects of PAI skills have not been affected been developed optimally. The PAI learning process still tends to be a process of transferring and absorbing information in curriculum content. In the implementation of PAI learning, the teacher is still oriented to the completion of the material. The teacher teaches PAI subject matter by reading the textbook. In evaluation activities, the teacher demands the students' answers exactly as he explained.

Students are not given broad opportunities to think creatively and express their opinions freely. They are used to taking notes and listening to the teacher's explanation. Students are more in learning behavior to listen to information with dominant teacher activities. Teachers take more positions in front of the class, which tends to be patronizing rather than teaching students to think about lesson materials. The pattern of education in schools causes children to be unable to freely carry out activities according to their will so that the creative power of children is reduced.

The results of interviews with several $X$-grade students who have participated in PAI lessons show that they are aware of the importance of mastering 4Cs skills. For this reason, a teacher is required to develop various models and or learning methods that can be applied to PAI learning. The problems faced by teachers in classroom learning require teachers always to think, give serious attention, in-depth consideration of events or decisions taken. Teachers need and are essential to prepare all tools such as curriculum, lesson plans, and models or methods integrated with 4Cs skills. By developing 4Cs skills in learning, it is hoped that every individual has the skills to live in the 21st century with various opportunities and challenges that will be faced in the era of technological and information advancement.

Besides being responsible for developing character and literacy, PAI learning is also responsible for developing 4Cs Skills, namely; Communication, Collaboration, Critical Thinking, and Problem Solving Creativity and Innovation. Many learning models can be used to create 4Cs skills in learning, one of which is the Blended Learning model with the e-poster comment method. There are several reasons why Blended Learning with the e-poster comment method was chosen to develop 4Cs Skills: (1) The e-poster comment method is a method used by educators to invite students to come up with ideas about what is contained in an image.; (2) the e-poster comment method is a part of active learning; (2) the e-poster comment method is student-centered, teamwork, and knowledge related to the context of everyday life.

Based on this description, developing learning that demands 4Cs skills is essential and must be a teacher's attention. Therefore, this study aims to create 4Cs Skills through a blended learning model of the e-poster comment method on Islamic Religious Education and Moral Character. The researcher chose SMAN 27 Bandung as the research location because this school has been accustomed to applying the e-poster comment method for learning Islamic Religious Education and Budi Poker.

\section{METHOD}

The approach used in this research is qualitative with a descriptive-analytical method. Data were collected through observation, interviews, and documentation studies. The subjects of this study were 
teachers, students, school principals, and vice-principals in the field of curriculum.

The research was carried out by collecting data in advance from the field, which in this case, the research location was SMAN 27 Bandung City. The research data obtained through several collection techniques are then analyzed by reducing the data according to the needs of the research focus. The data that has been reduced is then presented, and conclusions are drawn.

The key informants in this study were PAI teachers, while other supporting data were obtained through additional informants, namely several teachers and students. Checking the validity of the data is carried out by researchers to account for the truth of the information that has been obtained. The data is carried out through credibility techniques, including triangulation, an extension of observation time, increasing persistence, and referential adequacy.

\section{RESULTS AND DISCUSSION}

\section{A. Skill 4Cs}

The development of the 21st-century world is marked by the development and use of information and communication technology in all areas of life. In the world of work, the development of the world demands changes to the competence of each individual. These competencies include thinking critically, solving problems, and collaborating (Abu Anwar, Amir, \& Sari, 2020). In the world of education, students' success is seen from their academic abilities and the abilities and skills that can help students compete in the global and digital world that is developing today. Because future work is no longer routine work as it is today, but creative work is the highest type of work. In contrast, regular work that humans usually do will be replaced by robot technology and automation (Fathurrochman, Danim, AB, Kurniah, \& Ristianti, 2021).

Critical thinking skills are skills that students must possess related to decisionmaking in solving daily problems. According to John Dewey, critical thinking is an active, persistent, and thorough consideration of a belief or form of knowledge taken for granted regarding the reasons that support it and the further conclusions it tends to draw (Gelman \& Waxman, 2007).

Critical thinking is an active process in which a person thinks deeply about things, asks questions, and finds relevant information for himself rather than accepting things from others. Elaine $B$. Johnson said that the purpose of critical thinking is to achieve deep understanding (PRATIWI, Darmawijoyo, \& Hartono, 2016). Meanwhile, Fahruddin Faiz stated that the goal of critical thinking is simple, namely to guarantee, as far as possible, that our thinking is valid and correct. With the ability to think critically, students should be able to solve the problems they face.

Critical thinking can also be a skilled activity that can be done better or vice versa. Good critical thinking should meet various intellectual standards, such as clarity, relevance, adequacy, coherence. Critical thinking clearly demands the interpretation and evaluation of observations, communications, and other sources of information. It also requires thinking through assumptions, asking relevant questions, and drawing implications (Gelman \& Waxman, 2007).

Based on these various opinions, it appears that there are similarities in critical thinking systematics. Namely, the necessary thinking process must go through several stages to arrive at the assessment or conclusion stage. So it can be understood that critical thinking is a process of thinking about a problem indepth, synthesizing it to solve a problem.

Trilling and Fadel stated that critical thinking skills are individual abilities to reason effectively, ask questions and solve problems sharply, analyze and evaluate alternative views, and reflect on processes and decisions. According to Ennis, there are five types of critical thinking categories: 1) Clarification at the primary level (elementary clarification), 2) essential support (basic support), 3) inference (inferring), 4) further clarification (advanced clarification), 5) strategy and tactics (strategies and tactics). (Suryandari, Kadarisman, \& Sudomo, 2018) 
Table 1

Critical Thinking Skills Indicator (Rusyna, 2014)

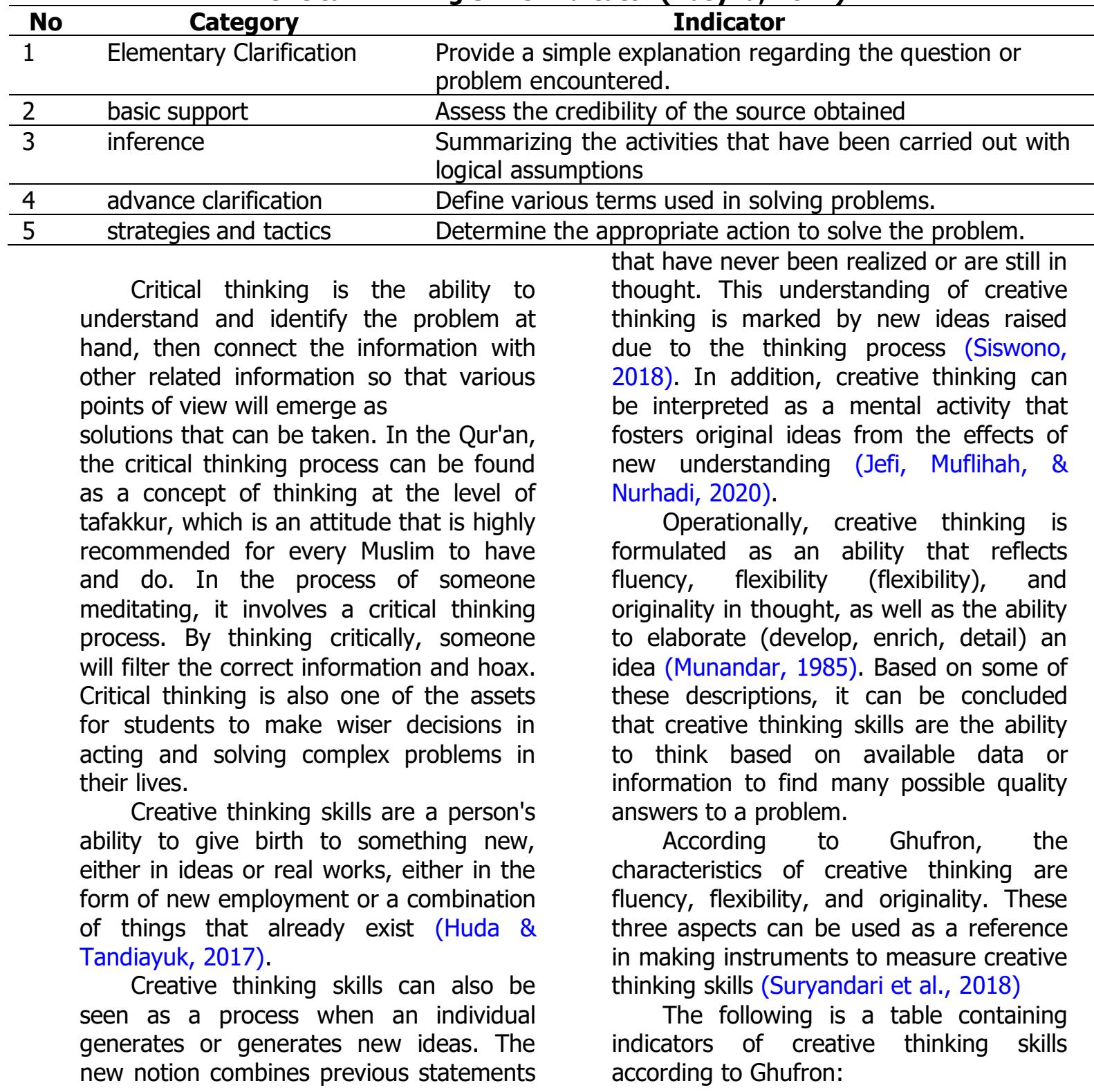

Table 2

Creative Thinking Skills Indicator

\begin{tabular}{lll}
\hline No & $\begin{array}{l}\text { Characteristics } \\
\text { Creative Thinking }\end{array}$ & \multicolumn{1}{c}{ Indicator } \\
\hline 1 & Fluency & Mention many solutions to solve problems. \\
\hline 2 & Flexibility & $\begin{array}{l}\text { Provide answers or solutions that are different from } \\
\text { the others. }\end{array}$ \\
\hline 3 & Originality & $\begin{array}{l}\text { We are creating new solutions or answers that have } \\
\text { never been used before to solve problems. }\end{array}$ \\
\hline
\end{tabular}

In the realm of creativity (creativity), Islam also does not prevent its adherents from creating and innovating as long as the invention does not violate Islamic provisions and as long as it is intended for goodness, refine the mind, and for the improvement and improvement of the quality of life and health of the people. So that there will be people who are rich in 
creativity, do not think monotonously about a problem, but dare to think outside the box and dare to take all challenges. If this concept is carried out continuously and continuously through a process of improvement and evaluation, Indonesia may Reach its golden age when our students complete their studies.

According to Hatfield Changara, communication skills are a person's ability to convey or send messages to the recipient of the message (Saputra, 2021).
Communication is an activity that is usually carried out by everyone in any scope, anywhere, and anytime. Everyone needs a thing called communication because everything becomes more understandable (Anita, n.d.).

The table below shows the indicators of communication skills adapted from indicators according to Trilling and Fadel (Wijayaningrum, 2016):

Table 3

Indicators of Oral and Written Communication Skills

\begin{tabular}{|c|c|c|}
\hline No. & \multicolumn{2}{|c|}{ Indicator } \\
\hline 1. & \multicolumn{2}{|c|}{$\begin{array}{l}\text { Articulate thoughts and ideas effectively using oral, written, and non-verbal } \\
\text { communication skills in various forms and contexts. }\end{array}$} \\
\hline 2. & \multicolumn{2}{|c|}{$\begin{array}{l}\text { Use communication for various purposes, such as to provide information or } \\
\text { instructions. }\end{array}$} \\
\hline 3. & \multicolumn{2}{|c|}{$\begin{array}{l}\text { Utilize a variety of media and technologies and know-how to assess their } \\
\text { effectiveness and assess their impact. }\end{array}$} \\
\hline 4. & \multicolumn{2}{|c|}{ Communicate effectively in diverse environments } \\
\hline \multicolumn{2}{|c|}{$\begin{array}{l}\text { Communication skills (communication } \\
\text { skills) also have a basis and footing in } \\
\text { Islamic teachings. The Prophet } \\
\text { Muhammad as the primary role model } \\
\text { (uswatun Hashanah) and a central figure, } \\
\text { has given many examples of how to } \\
\text { communicate effectively (effective } \\
\text { communication). Start the interaction by } \\
\text { greeting, sharing a smile, speaking } \\
\text { politely, gently, and using language and } \\
\text { good choice of words, and by the capacity } \\
\text { and thinking ability of the audience. } \\
\text { Collaboration or cooperation is a } \\
\text { symptom of approaching each other to } \\
\text { take care of common interests and goals. } \\
\text { Cooperation is also defined as an act of } \\
\text { mutual assistance or carried out together } \\
\text { to obtain or provide interpersonal service. } \\
\text { Collaborative learning is one of the best }\end{array}$} & $\begin{array}{l}\text { Ways to develop active learning } \\
\text { namely by giving group assignments tha } \\
\text { are completed in groups of students. The } \\
\text { collaborative learning process is not jus } \\
\text { working together in a group. Still, the } \\
\text { emphasis is more on a learning proces } \\
\text { that involves a complete and fai } \\
\text { communication process in the classroom } \\
\text { (Gunawan \& Genius, 2003). } \\
\text { Collaboration is working togethe } \\
\text { compactly and simultaneously to achieve a } \\
\text { goal (Asrori, 2007). The partnership } \\
\text { referred to by the researcher is the ability } \\
\text { of students to cooperate with classmates } \\
\text { to create equitable learning conditions ir } \\
\text { one class } \\
\text { The following table displays the } \\
\text { indicators of these skills, according to } \\
\text { Trilling and Fadel (Dewi, 2015): }\end{array}$ \\
\hline \multicolumn{3}{|c|}{$\begin{array}{c}\text { Table } 4 \\
\text { Collaborating Skills Indicator }\end{array}$} \\
\hline No. & \multicolumn{2}{|c|}{ Indicator } \\
\hline 1. & \multicolumn{2}{|c|}{$\begin{array}{l}\text { You have demonstrated the ability to work effectively and appreciate team } \\
\text { diversity. }\end{array}$} \\
\hline 2. & \multicolumn{2}{|c|}{$\begin{array}{l}\text { Demonstrate flexibility and willingness to assist in making the compromises } \\
\text { necessary to achieve a common goal. }\end{array}$} \\
\hline 3. & \multicolumn{2}{|c|}{$\begin{array}{l}\text { Share shared responsibility for collaborative work and value individual } \\
\text { contributions made by each team member. }\end{array}$} \\
\hline
\end{tabular}


Based on the explanation above, what is meant by collaboration skills in this study is the ability of individuals to cooperate effectively and responsibly

with different groups when carrying out group activities.

Islam commands its people to work together and help each other, especially doing good deeds regarding collaboration skills.

B. Blended Learning

The rapid development of technology requires innovation in learning. One of these innovations is Blended Learning. The concept of Blended Learning is mixing conventional learning models with online learning. Blended Learning comes from the words Blended and Learning. Blend means to mix and Learning means learning. From the two elements of the word, it can be seen that Blended Learning means mixing teaching patterns. According to Mosa in Rusman (Sutisna, Novita, \& Iskandar, 2020), mixed learning patterns are two main elements: learning in the classroom with online learning. In this online learning, there is learning using the internet network in which there is web-based learning.

Blended learning is the ease of learning that combines various delivery methods, learning models, and learning styles, introducing different media options between facilitators and students. Blended learning is also a combination of direct teaching (face to face) and online instruction.

Learning using internet media is not a mainstay because there is no interaction between teachers and students. In Teaching and Learning Activities (KBM), especially Islamic Religious Education lessons, face-to-face or conventional is the primary learning process carried out in most schools in Indonesia. However, this face-to-face KBM tends to make students bored and less active. For this reason, there is a need for learning innovation, namely by applying the concept of Blended Learning.

In the end, this learning model aims to achieve the effectiveness of learning, online learning, and face-to-face. This Blended learning involves class (or face to face) and online learning (e-learning). This method effectively adds efficiency to classroom instruction and enables increased discussion or review of information outside the classroom.

Educators use the e-poster comment method or comment on pictures to invite students to develop ideas about what is contained in an image. The concept, of course, must be related to the achievement of skill in learning.

E-Posters consist of text, images, or a combination of both. E-Poster is a graphic design in which pictures and words on large paper contain information and are pasted in public places so that many people can see or read. E-Posters are designed to attract the attention of many people. Posters can also be a means to promote products, services, activities, education, and others. Or the definition of an e-Poster is an image that contains information on large paper, which is pasted on the wall or in certain places so that many people can see it. In the process of arranging posters, certain design principles must be considered, including the principles of simplicity, cohesiveness, emphasis, and balance.

The following visual elements need to be considered: shape, line, space, texture, and color (Azhar, 2007). (1) Simplicity. The fewer elements make it easier for students to capture and understand the message presented by the visual. Long or complex messages or information should be divided into several visual materials that are easy to read and easy to understand, as well as the accompanying text of visual materials should be limited; (2) Integration Cohesiveness refers to the relationship that exists between visual elements which when observed will function together. The parts must be interrelated and unified so that a graphic is a comprehensive form that can be recognized and help understand the message and information it contains; (3) Emphasis. Although the visual presentation is designed, the concept to be presented often requires an emphasis on one element that will become the center of students' attention. By using size, relationships, perspective, color, or space (4) Balance. The shape or pattern chosen should occupy a viewing space 
that provides a perception of balance. Balance is a principle in composition that avoids the impression of bias on a field or area filled with visual elements. So, in designing pictures, educators must pay attention to these principles so that the expected learning objectives can be achieved optimally.

According to Sudjana and Rivai in their book entitled Teaching Media, several principles need to be considered in using pictures as visual media in every teaching activity, including: (1) Use pictures for specific learning purposes, namely by choosing certain pictures that will support the explanation of the core of the lesson or the main points of the lesson; (2) Integrate pictures into the lesson, because the effective use of photographic pictures in the teaching and learning process requires coherence; (3) Use the pictures sparingly, rather than using lots of pictures but not being effective. Save on the use of images that contain meaning. A small but selective number of pictures is better than twice showing random pictures without being picky; (4) Reduce the discussion of words in pictures, because pictures are essential in developing words or stories or in presenting new ideas; (5) Encouraging creative statements, through pictures students will be encouraged to develop oral and written language skills, graphic arts and other forms of activity; (6) Evaluating class progress, it can also be done by using pictures, both in general and in particular (Sudjana \& Rivai, 2010).

The steps for the e-poster comment method are as follows:

a. Topic introduction stage. The introduction of learning topics is done by holding a question and answer activity between teachers and students regarding the material on the provisions of dressing according to Islamic law,

b. Group formation stage. At the scene of group formation, the teacher forms 4 to 5 groups according to the number of students using the breakout facility on the zoom application.

c. The stage of presenting a poster with questions. At this stage, the teacher gives an e-poster about how to dress in the PowerPoint application.

d. The stage of observing the poster. Students attend the sign for comments in the form of questions or statements for approximately 5 minutes.

e. The stage of commenting on the poster personally. Students make a question or statement that must be written in PowerPoint.

f. Stage of choosing the best four comments. After that, each group must choose the best four questions or statements that can convey the contents of the picture.

g. The stage of presenting the results of group discussions. Each group presents the results of their group discussion. Students take turns giving opinions verbally in the form of approval, refutation, or rejection of views, along with reasons on the zoom application.

h. The stage of formulating the results of group discussions. Group representatives prepare provisions on how to dress by Islamic law. The teacher directs students to conclude the material.

C. Islamic Religious Education and Character (PAI and BP) in SMA

Etymologically, education comes from the word learn. In English, the word to educate and the word education are obtained. In a narrow sense, the word to educate in the form of a verb or verb is to teach or help someone learn, which means "to teach or help someone who is learning" ( $\mathrm{Na}$ 'im, n.d.).

Education is generally defined as a conscious and planned effort made by teachers to develop all the potential of students optimally (Wiyani, 2012). Meanwhile, Theodore Mayer Greene describes education as a human effort to prepare himself for a meaningful life (Tafsir, 2000). According to Haryanto AlFandi, education is a continuous process that contains elements of teaching, training, guidance, and leadership with a specific focus on transferring various knowledge, religious and cultural values, and skills that are useful to be applied by 
teachers to individuals who need the education. (Herson Anwar, 2019).

From some of the opinions above, it can be concluded that education is a conscious and planned effort by teachers that contains elements of teaching, training, and guidance in developing students' potential optimally to prepare themselves for a meaningful life.

In the context of Islam, the notion of education refers to the terms commonly used, namely, ta'lim, tarbiyah, and tab. The term ta'lim with the verb 'Allama contains the meaning of telling or giving knowledge. So, this term can be interpreted as teaching, as in Arabic, the term tarbiyah fatalism is often used to mean education and teaching (Herson Anwar, 2019).

Meanwhile, the term tarbiyah, which in the Arabic dictionary comes from fi'il made robbed and its mudhari yurobba, which means to maintain, nurture and educate. In the form of masdar, it becomes tarbiyah, which means maintenance, upbringing, and education. From this understanding, it can be understood that the concept of tarbiyah is a process of educating humans to improve human life in a better direction. Then, the term tail is linguistically a masher form of the word addaba which means adab and educates (Herson Anwar, 2019).

Ahmad D. Marimba (Marimba, 1980) argues that Islamic education is physical and spiritual guidance based on Islamic religious laws leading to the formation of a personality that has Islamic values (Ma'rufah, 2019). Meanwhile, according to Zakiah Darajat, as quoted by Fatah Syukur, Islamic education is more shown to improve mental attitudes that will be realized in deeds, both for the needs of oneself and others that are theoretical and practical (Kamal, 2018).

According to Burian Somad, as quoted by Nur Uhbiyati, Islamic education is education that aims to form the highest self-characterized individual according to the size of the Qur'an. The content of education is the teachings of Allah as stated in the Qur'an, whose implementation is in the practice of daily life as exemplified by the Prophet Muhammad (Ma'rufah, 2019).
Meanwhile, according to Maksum, as quoted by Haryanto Al-Fandi, Islamic education is all educational processes that are sourced from the Qur'an, the Sunnah of the Prophet, the words and deeds of friends, and the ijtihad of the scholars to form a solid Muslim personality and able to overcome problems. In life in an Islamic way so that the ultimate goal is achieved, namely happiness in the world and the hereafter with the pleasure of Allah (Herson Anwar, 2019).

Meanwhile, according to Ahmad Tafsir, education must educate humans to become humans (Sulaiman, 2019). The purpose of education is to increase a high human being; that is what can be called a human being. One method that can be used is the internalization method. The internalization method has three learning objectives: (1) Knowing, knowing. Here the teacher's task is to make students see a concept; (2) be able to carry out or do what he knows (doing); (3) The disciple becomes what he knows. This concept should belong to him and become one with his personality (Sulaiman, 2019).

Islam itself comes from two words with different meanings: "religion" and "Islam." Many experts say that religion comes from Sanskrit, namely "a," which means not, and "game," which means chaotic. So religion means not chaotic (orderly). Thus religion is a regulation, namely a regulation that regulates the human condition and regarding something supernatural, regarding character and social life together (Ismail \& Islam, 1997).

There are several other terms of religion, including religion, religion (English), religie (Dutch), religion/relegate (Latin), and dien (Arabic). The words religion (English) and religie (Dutch) are derived from the parent language of the two languages, namely Latin "religion" from the root word "relegate," which means binding (Kahmad, 2002). According to Cicero, relegate means doing something with great suffering, namely the type of worship done repeatedly and steadily. Lactantius defines relegate as binding together in a common union (Ismail \& Islam, 1997). In Arabic, religion is known as al-din and al-Milah. The word al-din itself contains various meanings. It can 
mean al-Mulk (royal), al-khidmat (service), al-izz (glory), al-dull (disgrace), al-nikah (coercion), al-Ihsan (benevolence), al-adat (habits of ), al-ibadat (devotion), al-qasr was al-sultan (power and government), altadzallulwa al-kudu (submission and obedience), al-that (compliance), al-Islam al-tauhid ( surrender and unite God) (Kahmad, 2002).

Glock and Stark define religion as a system of symbols, belief systems, value systems, and institutionalized behavioral systems centered on issues that are internalized as the most meaningful (Amawidyati \& Utami, 2007). Clifford Geertz defines religion as a system of symbols that acts to establish intense, pervasive, and enduring moods and motivations in human beings by formulating concepts of a general order of existence and wrapping these concepts in a kind of radiance of factuality so that attitudes and motivations appear realistic (Geertz, 1992).

According to Hadikusuma in Bustanuddin Agus, religion is teaching revealed by God to guide people in living their lives (Agus, 2006). Some call faith a universal feature of human social life because all societies have ways of thinking and behavior patterns that meet "religion," consisting of symbols, images, beliefs, and values. Precisely, human beings interpret their existence, including a ritual component (Ishomuddin, 2002).

While the word Islam is a derivative of the phrase assalmu, assalamu, assalamatu, which means clean and safe from physical and mental defects. Other meanings of Islamic derivatives are "peace" or "peace" and "security." Ahmad Abdullah Almasdoosi terminologically expresses the understanding of Islam as a rule of life that contains clear and complete guidance regarding aspects of human life, both spiritual and material (Awaliyah, 2019). To understand Islam more broadly, it is necessary first to understand the basics of Islam or what is often called the basic framework of Islamic teachings. By understanding this basic framework, one can understand the overall picture of Islamic teachings.

Thus Islamic Religious Education is an effort in the form of guidance and care for students so that later after completing their education, they can understand and practice Islamic teachings. Islamic Religious Education in this discussion is positioned as one of the fields of study that every student must follow, both in public schools and in private schools. Islamic Religious Education and Character Education are previously known as Islamic Religious Education (PAI) subjects. The change in the vocabulary of PAI subjects to Islamic Religious Education and Character Education is intended to strengthen the mission of Islamic teachings to be more grounded and universal. Juridically, the name change refers to PP No.32/2013, the explanation of Article 77 Paragraph (1) Letter a: that religious education is intended to shape students into human beings who believe and fear God Almighty and have a noble character, including character. (Ismail \& Islam, 1997).

The subject of Islamic Religious Education is one of the fields of study that is presented to high school students by Law no. 20/2003 concerning the National Education System; it is stated that national education functions to develop capabilities and shape the character and civilization of a dignified nation in the context of educating the nation's life, aiming at developing the potential of students to become human beings who believe and fear God Almighty, have noble character. Healthy, knowledgeable, capable, creative, independent, and become a democratic and responsible citizen.

Islamic religious education in high school consists of four primary materials, namely: Qur'an-Hadith, Aqidah-akhlak, Figh, and Dates (History) of Islamic Culture. Each of these subjects is interrelated, complementary, and complementary. Al-Qur'an-Hadith is the primary source of Islamic teachings, which is the source of aqidah-morals, and shari'ah/fiqh (worship, muamalah), so the study is in each of these elements. Aqidah or faith is the root or principle of religion, while shari'ah/fiqh is a system of norms regulating human relations with Allah, fellow humans, and other creatures. In contrast, the date (history) of Islamic culture is the development of the life 
journey of Muslim humans from time to time in the sharia business (worship and muamalah) and morals and developing a life system based on aqidah.

Each subject has specific characteristics or characteristics that can distinguish it from other issues, including Islamic Religious Education and Character Education (PAI \& BP). The features of Islamic Religious Education in question are as follows:

a. Islamic Religious Education is a group of subjects developed from the fundamental teachings contained in Islam.

b. In terms of content, Islamic Religious Education is the main subject which is one of the components and cannot be separated from the group of topics that aim to develop the morals and personality of students.

c. The purpose of Islamic Religious Education is to form students who believe and fear Allah SWT, have noble character (have good morals), know the central teachings of Islamic teachings and practice them in daily life, and have broad and deep knowledge about the teachings of Islam. Islam is therefore adequate both for people's lives and for continuing to study at a higher level.

d. Islamic Religious Education (PAI), a learning program, is directed at 1) maintaining the aqidah and devotion of students, 2) being the basis for being more diligent in studying other sciences taught in schools/madrasas, 3) encouraging students to be critical, creative and innovative, and 4) become the foundation in everyday life (building social ethics).

e. Islamic Religious Education Learning (PAI) emphasizes the mastery of cognitive skills and affective and psychomotor.

f. The content of Islamic Religious Education (PAI) subjects is based on and developed from the provisions contained in the primary sources of Islamic teachings, namely the Qur'an and the Sunnah of the Prophet Muhammad (peace be upon him). In addition, the material for Islamic religious education (PAI) is also enriched with the results of Sinbad or ijtihad (dalil all) of The scholars so that the central teachings of a general nature are more detailed and detailed.

g. Islamic Religious Education Materials (PAI) were developed from three basic frameworks of Islamic teachings, namely aqidah, shari'ah, and akhlaq.

Muhaimin stated the characteristics of Islamic Religious Education as follows:

Islamic religious education and good manners are aimed at being able to harmonize, harmonize, and balance between faith, Islam, and insan, which is manifested in the human relationship with Allah SWT, the relationship between humans and themselves, human relationships with fellow humans, and human relationships with their natural environment.

\section{CONCLUSION}

Islamic Religious Education (PAI) learning in developing the skills of 4Cs, in general, can be implemented well with the achievement of indicators of the skills of 4Cs. Pai's learning process to establish 4Cs in SMAN 27 Bandung city was quite effectively marked by most students enthusiastic in following the learning marked by their seriousness following the teaching, giving opinions during discussions, and responding to the views of their friends. Students understand the material quite well, characterized by the ability to provide a statement and choose one of the existing images according to the group question in the e-poster accompanied by the reasons.

\section{REFERENCES}

Afandi, Thohir. (2017). Bonus Demografi 2030-2040: Strategi Indonesia Terkait Ketenagakerjaan Dan Pendidikan. Jakarta: Kementrian Perencanaan Pembangunan Nasional.Google Scholar

Agus, Bustanuddin. (2006). Agama Dalam Kehidupan Manusia: Pengantar Antropologi Agama. Rajagrafindo Persada (Rajawali Pers). Google Scholar

Amawidyati, Sukma Adi Galuh, \& Utami, Muhana Sofiati. (2007). Religiusitas Dan Psychological Well-Being Pada Korban Gempa. Jurnal Psikologi, 34(2), 164- 
176. Google Scholar

Anita, Wilfa. (N.D.). Pengaruh Komunikasi Dalam Keluarga Terhadap Perilaku Moral Anak Usia 5-6 Tahun Di Tk FkipUnri Pekanbaru. Google Scholar

Anwar, Abu, Amir, Zubaidah, \& Sari, Intan Kartika. (2020). Pengaruh Project Based Learning Terhadap Motivasi Belajar Sekolah Dasar Negeri 167 Pekanbaru. Google Scholar

Anwar, Herson. (2019). College Students' Perception About The Implementation Of Democratic And Humanist Learning Model In State Islamic Institute (Iain) Sultan Amai Gorontalo. Nadwa, 12(2), 273-292. Google Scholar

Asrori, Mohammad. (2007). Penelitian Tindakan Kelas. Bandung: Cv Wacana Prima. Google Scholar

Awaliyah, Rifa. (2019). Implikasi Menghafal Al-Qur'an Terhadap Akhlak Anak: Penelitian Di Madrasah Al-Maaliyah Kecamatan Bayongbong Kabupaten Garut. Uin Sunan Gunung Djati Bandung. Google Scholar

Azhar, Arsyad. (2007). Media Pembelajaran, Jakarta: Pt. Raja Grafindo Persada, 1585. Google Scholar

Dewi, Finita. (2015). Proyek Buku Digital: Upaya Peningkatan Keterampilan Abad 21 Calon Guru Sekolah Dasar Melalui Model Pembelajaran Berbasis Proyek. Metodik Didaktik: Jurnal Pendidikan Ke$S d-A n$, g(2). Google Scholar

Fathurrochman, Irwan, Danim, Sudarwan, Ab, Syaiful Anwar, Kurniah, Nina, \& Ristianti, Dina Hajja. (2021). Theoretical Review Of The Implementation Islamic Boarding School Curriculum Management In Indonesia. International Journal Of Education Research And Development, 1(1), 1-15. Google Scholar

Geertz, Clifford. (1992). Kebudayaan Dan Agama, Terj. Francisco Budiman Hardiman. Yogyakarta: Kanisius. Google
Scholar

Gelman, Susan A., \& Waxman, Sandra R. (2007). Looking Beyond Looks: Comments On Sloutsky, Kloos, And Fisher (2007). Google Scholar

Gunawan, Adi, \& Genius, Learning Strategy. (2003). Petunjuk Praktis Untuk Menerapkan Accelerated Learning. Jakarta: Pt Gramedia Pustaka Utama. Google Scholar

Hariyanto, Ismet Basuki. (2014). Asesmen Pembelajaran. Bandung: Pt. Remaja Rosdakarya. Google Scholar

Huda, Nurul, \& Tandiayuk, Marinus B. (2017). Profil Berpikir Kreatif Siswa Dalam Memecahkan Masalah Segitiga Berdasarkan Tingkat Kemampuan Matematis Kelas Vii Smp Negeri 1 Palu. Jurnal Elektronik Pendidikan Matematika Tadulako, 4(3), 382-396. Google Scholar

Ishomuddin, Pengantar Sosiologi Agama. (2002). Ghalia Indonesia. Jakarta. Google Scholar

Ismail, Faisal, \& Islam, Paradigma Kebudayaan. (1997). Studi Kritis Dan Refleksi Historis. Yogyakarta: Titian Ilahi Press. Google Scholar

Jefi, Jefi, Muflihah, Muflihah, \& Nurhadi, Mukhamad. (2020). Penurunan Miskonsepsi Siswa Melalui Pembelajaran Remedial Dengan Menggunakan Model Pembelajaran Induktif Pada Materi Reaksi Reduksi Dan Oksidasi. Bivalen: Chemical Studies Journal, 3(1), 4-8. Google Scholar

Kahmad, Dadang. (2002). Sosiologi Agama, Bandung. Penerbit Pt Remajarosdakarya. Google Scholar

Kamal, Faisal. (2018). Transformasi Pendidikan Pesantren Sebagai Lembaga Pendidikan Islam Abad 21. Paramurobi: Jurnal Pendidikan Agama Islam, 1(2), 17-30. Google Scholar

Ma'rufah, Amanatul Ardliana. (2019). 
Pengaruh Motivasi Belajar Terhadap Pencapaian Indeks Prestasi Semester Genap: Studi Komparatif Mahasiswa Bekerja Dan Tidak Bekerja Program Studi Manajemen Pendidikan Islam (Mpi) Angkatan 2016/2017 Fakultas IImu Tarbiyah Dan Keguruan Uin Walisongo Semarang. Uin Walisongo. Google Scholar

Marimba, Ahmad D. (1980). Pengantar Filsafat Pendidikan Islam, Bandung: Pt. A/ Ma'arif. Google Scholar

Munandar, S. C. Utami. (1985). Mengembangkan Bakat Dan Kreativitas Anak Sekolah: Penuntun Bagi Guru Dan Orang Tua. Gramedia. Google Scholar

Na'im, Zaedun. (N.D.). Madrasah: Between Tradition And The Demands Of Change In Modern Civilization.

Pratiwi, Ismel D. W. I., Darmawijoyo, Darmawijoyo, \& Hartono, Yusuf. (2016). Kemampuan Berpikir Kritis Siswa Dalam Pembelajaran Matematika Dengan Pendekatan Contextual Teaching And Learning (CtI) Di Kelas Vii Smp Negeri 1 Kikim Timur. Sriwijaya University. Google Scholar

Saputra, Febryan. (2021). Komunikasi Antar Pribadi Mahasiswa Dengan Teman Akrab Dalam Pembentukan Konsep Diri (Studi Kasus Pada Mahasiswa IImu Komunikasi 2014 Universitas Muhammadiyah Malang). Universitas Muhammadiyah Malang. Google Scholar

Siswono, Tatag Yuli Eko. (2018). Pembelajaran Matematika Berbasis Pengajuan Dan Pemecahan Masalah. Bandung: Remaja Rosdakarya. Google Scholar
Sudjana, Nana, \& Rivai, Ahmad. (2010). Media Pengajaran. Bandung: Sinar Baru Algensindo. Google Scholar

Sulaiman, Sulaiman. (2019). Hakikat Manusia Sebagai Pendidik Dalam Perspektif Filsafat Pendidikan Islam. Auladuna: Jurnal Prodi Pendidikan Guru Madrasah Ibtidaiyah, 1(1), 91-99. Google Scholar

Suryandari, S., Kadarisman, N., \& Sudomo, J. (2018). Perbedaan Keterampilan Berpikir Kritis Siswa Yang Berbantuan Media Audio Visual Dan Lks Cetak Sebagai Panduan Percobaan Pada Metode Eksperimen Dengan Pendekatan Verifikasi Kelas Xi Sma Negeri 1 Sewon. Jurnal Tarbiyah: Jurnal IImiah Kependidikan, ス1), 37-40. Google Scholar

Sutisna, Entis, Novita, Lina, \& Iskandar, M. Iqbal. (2020). Penggunaan Media Pembelajaran Berbasis Teknologi, Informasi, Dan Komunikasi Dalam Meningkatkan Hasil Belajar Subtema Lingkungan Tempat Tinggalku. Pedagonal: Jurnal IImiah Pendidikan, 4(1), 1-6. Google Scholar

Tafsir, Ahmad. (2000). Metodologi Pengajaran Agama Islam. Google Scholar

Wijayaningrum, Wahyu. (2016). Profil Kemampuan Komunikasi Matematis Dalam Pembelajaran Model Kooperatif Tipe Formulate-Share-Listen-Create (Fs/c) Ditinjau Dari Penalaran Matematis Siswa Di Smpit At-Taqwa Surabaya. Uin Sunan Ampel Surabaya. Google Scholar

Wiyani, Novan Ardy. (2012). Pendidikan Karakter Berbasis Iman Dan Taqwa. Teras. Google Scholar

\section{Copyright holder:}

Edi Prihadi (2021)

First publication right:

Journal of Social Science

This article is licensed under: 